\title{
Lost in combat? A scrap metal find from the Bronze Age battlefield site at Tollense
}

Tobias Uhlig ${ }^{1}$, Joachim Krüger ${ }^{2}$, Gundula Lidke ${ }^{3}$, Detlef Jantzen ${ }^{4}$, Sebastian Lorenz ${ }^{5}$, Nicola Ialongo ${ }^{1} \&$ Thomas Terberger ${ }^{1,6, *}$

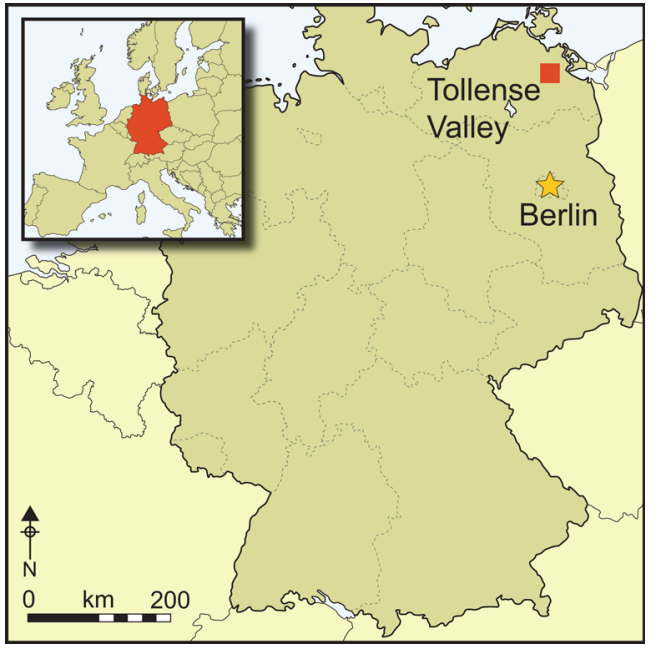

A decade ago, archaeologists discovered the site of a Bronze Age battlefield in the Tollense Valley in north-eastern Germany. Dated to the early thirteenth century $B C$, the remains of over 140 individuals have been documented, along with many associated bronze objects. Here, the authors present a new assemblage of 31 objects from the site, including three bronze cylinders that may be the fastenings of an organic container. The objects are similar to those found in Bronze Age burials of southern Central Europe, and may represent the personal equipment of a warrior from that region who died on the battlefield in Northern Europe.

Keywords: Germany, Tollense Valley, Bronze Age, warfare, conflict, bronze fastenings

\section{Introduction}

Finds from the Tollense Valley in north-eastern Germany represent the first archaeological evidence of a large violent conflict dated to the Nordic Bronze Age (c. 2000-1200 cal BC) (Jantzen et al. 2011; Terberger et al. 2014; Lidke et al. 2015, 2018). Since 2008, a research team has recovered human bones, weapons and many other bronze objects through

1 Department for Pre-and Protohistory, University of Göttingen, Nikolausberger Weg 15, Göttingen D-37073, Germany

2 Department of History, University of Greifswald, Domstrasse 9a, Greifswald D-17489, Germany

3 Schloßstraße 50, Berlin 14059, Germany

4 State Agency for Heritage Service of Mecklenburg-Vorpommern, Domhof 415, Schwerin D-19056, Germany

5 Institute for Geography and Geology, University of Greifswald, Friedrich-Ludwig-Jahn-Strasse 16, Greifswald D-17489, Germany

6 State Agency for Heritage Service of Lower Saxony, Scharnhorststrasse 1, Hannover 30175, Germany

* Author for correspondence (Email: thomas.terberger@phil.uni-goettingen.de)

(C) Antiquity Publications Ltd, 2019. This is an Open Access article, distributed under the terms of the Creative Commons Attribution-NonCommercial-NoDerivatives licence (http://creativecommons.org/licenses/by-nc-nd/ $4.0 /$ ), which permits non-commercial re-use, distribution, and reproduction in any medium, provided the original work is unaltered and is properly cited. The written permission of Cambridge University Press must be obtained for commercial re-use or in order to create a derivative work.

ANTIQUITY 93371 (2019): 1211-1230

https://doi.org/10.15184/aqy.2019.137 


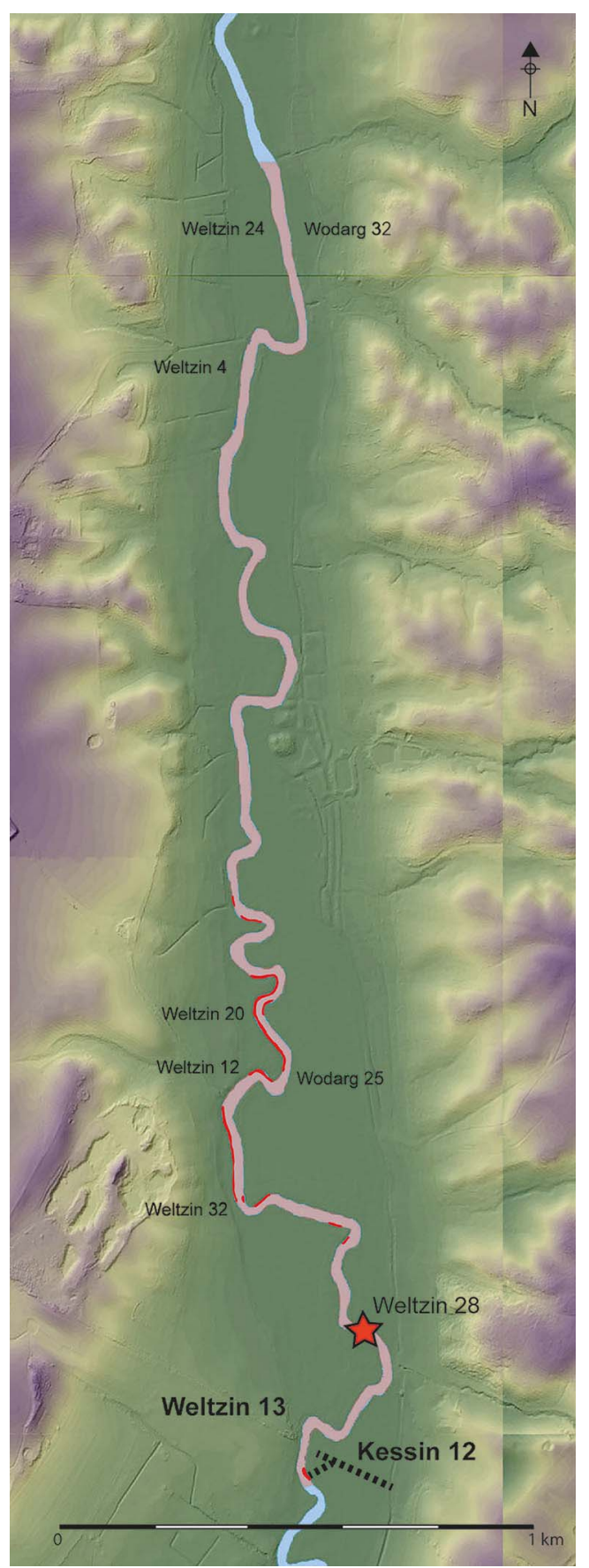

Figure 1. The Tollense Valley with the presence of the finds layer (in red) and the location of more important Bronze Age sites. Star) location of Weltzin 28; dotted line) preliminary reconstruction of the extension of the trackway (figure by J. Dräger \& $T$. Terberger).

(C) Antiquity Publications Ltd, 2019 a combination of diving, excavation and metal detecting. The finds come from different locations along a $2.5 \mathrm{~km}$-stretch of the Tollense River (Figure 1). The most important of these sites are Weltzin 20 , where the battlefield finds layer is preserved on the Bronze Age riverbank, approximately $1-1.5 \mathrm{~m}$ below present ground level, and Weltzin 32, representing the Bronze Age riverbed, with finds $2.5 \mathrm{~m}$ or more below ground level. Most of the bronze finds, including many arrowheads, were collected from dredged river sediments. Some arrowheads, both of flint and of bronze, were recovered during excavation, demonstrating their relationship to the battlefield finds layers. Several radiocarbon dates on fragments of wooden arrowshafts assign the finds to the early thirteenth century cal BC (1300-1250 cal BC; period III of the northern Bronze Age) (Terberger \& Heinemeier 2014; Terberger et al. 2018).

The recovery of more than 12000 pieces of human bone from the valley enables the identification of more than 140 individuals. Most of these remains were not preserved in their anatomically correct positions, having been moved by water action following decomposition (Figure 2) (Brinker et al. 2014). Most of the individuals represent young adult males in good physical condition (Brinker et al. 2014). The unusual age and sex profiles, combined with evidence for trauma on some bones indicating the use of close- and long-range weapons, support the hypothesis that the remains are those of combat victims. Furthermore, evidence for a number of healed traumatic lesions may suggest that these individuals were trained for, and accustomed to, fighting. The first results of aDNA and isotope (strontium, carbon 


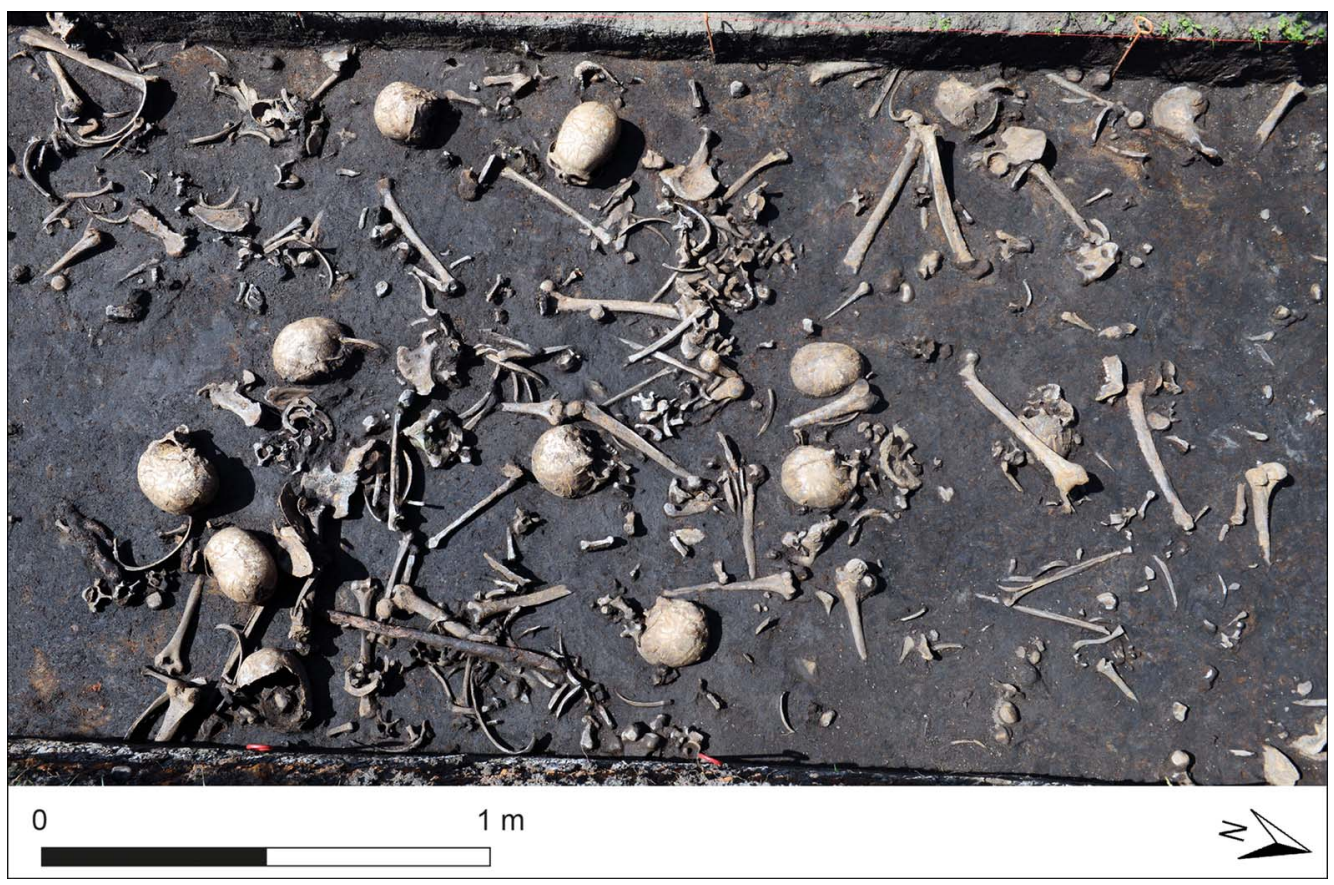

Figure 2. Photograph of the battlefield finds layer at site Weltzin 20; for the location of the site, see Figure 1 (photograph by S. Sauer).

and nitrogen) analyses indicate a heterogeneous group composition, with at least some nonlocals present (Terberger \& Heinemeier 2014; Price et al. 2017).

The battlefield finds-layer in general starts upstream at a nineteenth century cal BC causeway across the river valley (sites Weltzin 13/Kessin 12), which probably became an important focus for trade routes (Figure 1) (Jantzen et al. 2017). We suggest that the causeway was the starting point of the battle, c. 1300-1250 cal BC, which perhaps involved more than 2000 combatants (Lidke et al. 2015, 2018; Terberger et al. 2018). The multiple findspots of skeletal remains downstream of the causeway are probably the result of warrior groups killed in action as they moved along the riverbank. At Weltzin 20, many human bones have been recovered (minimum number of individuals $=83$ ), but the dearth of personal equipment and bronze objects suggests that such items may have been looted from the corpses after the battle. At other locations, such as Weltzin 32, corpses probably ended up in the river, thereby explaining the presence of valuable objects within fluviatile sediments (Krüger et al. 2012; Jantzen \& Terberger 2018). Post-battle offerings must also be taken into consideration, even though differentiating these from unintentional losses remains difficult. We can thus interpret the many metal objects recovered as the result of activities that occurred before, during and after the battle. The dominance of bronze finds from period III and the cluster of radiocarbon dates from fragments of arrowshafts suggest the close chronological connection of all of these activities. In 2016, a new assemblage of bronze finds was discovered in situ in the Tollense Valley. Here, we present the material for the

(C) Antiquity Publications Ltd, 2019 
first time, arguing that the assemblage may represent a small toolbox, containing the personal belongings of a warrior who fell during the battle, and providing new insights into the wider battlefield site.

\section{Materials and methods}

The assemblage was located in the riverbed at Weltzin 28, about $300 \mathrm{~m}$ downstream of the causeway, where the river is about $12 \mathrm{~m}$ wide and $2-2.5 \mathrm{~m}$ deep (Figure 1 ). A number of bronze objects, such as tools, dress-pins and a socketed bronze arrowhead, had been previously discovered at this site (Ulrich 2008; Dombrowsky 2014). In 2016, we made new finds in the riverbed during diving surveys (Figure 3) - the most important being the discovery of a small scrap metal assemblage of 31 bronze objects located above a layer of peat and sand (Figure 4). The tightly grouped objects were probably originally packed within an organic container.

At the top of the deposit was a bronze awl with a wooden (birch) handle and a knife. Below, were a chisel, fragments of bronze sheet, three cylindrical objects, at least three ingot fragments and an array of small bronze pieces, such as casting waste and scraps. In addition, a decorated belt box (type Dabel, after Hundt 1997) (Figures 3 \& 5), as well as three dress pins, a bronze spiral, a human cranium and a rib, were recovered from the same findspot. Approximately 3-4m away, we discovered a bronze arrowhead, a bronze knife with a bone handle, a dress pin with a spiral head and a second socketed bronze arrowhead with part of its wooden shaft attached (Figure 3). In 2018, the discovery of a third socketed bronze arrowhead indicates the continuation of the finds layer some $12 \mathrm{~m}$ farther west. This is also corroborated by the discovery of more human remains, including two skulls, another $12 \mathrm{~m}$ farther west. Taken together, this evidence indicates that Weltzin 28 was part of the wider Bronze Age battlefield.

All of the metal objects were subject to macro- and microscopic examination and were assigned, where possible, to typologies. Use-wear analysis was conducted with a digital microscope and elementary analyses undertaken with a portable XRF analyser (Niton

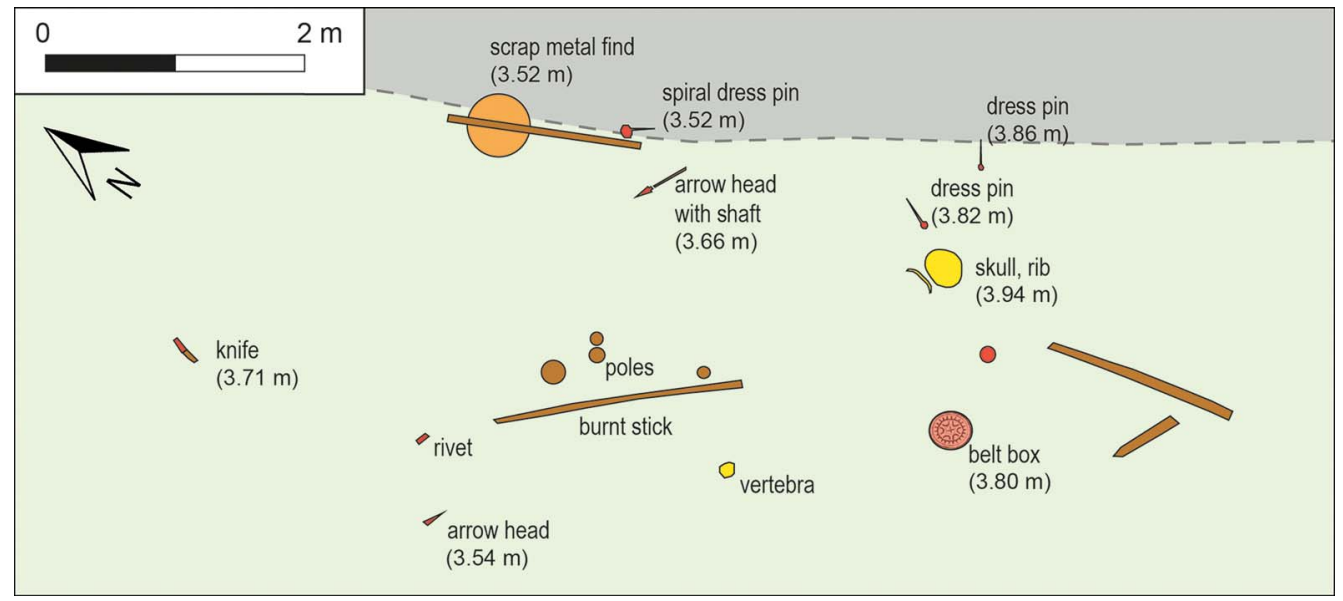

Figure 3. Distribution of finds at Weltzin 28 in the riverbed: yellow) human bone; red) bronze object; brown) wood; dotted line) transition from riverbed to stratigraphy; measurements given in $m$ asl (figure by $T$. Uhlig \& T. Terberger).

(C) Antiquity Publications Ltd, 2019 


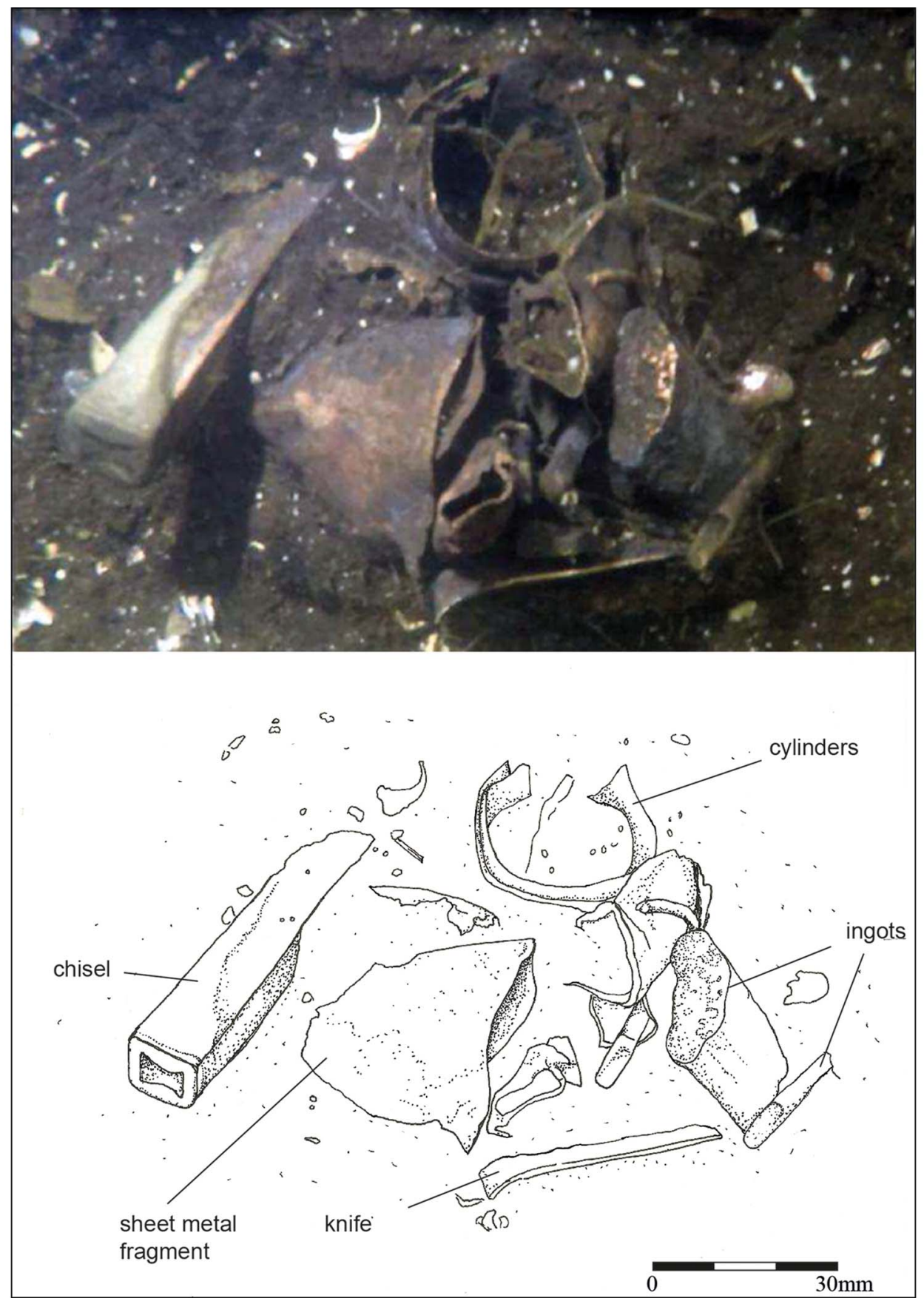

Figure 4. Photograph and drawing of the assemblage discovered at Weltzin 28; the limited quality of the former is due to the underwater conditions (photography by F. Nagel; drawing by T. Uhlig). 
ThermoScientific XL3t) to provide preliminary alloy determinations. Wood species were identified by M. Schult, and four samples were obtained for AMS dating.

\section{AMS dating}

A sample of the birch awl handle was AMS dated to 1275-1180 cal BC (MAMS 29473: $2988 \pm 24 \mathrm{BP}$ ), corresponding to the (late) period III. AMS dates on the dogwood arrow shaft and the wood remains inside the socket of the arrowhead-which probably belong to the same arrow-correspond well with dates of 1310-1225 cal BC (MAMS 29471: $3010 \pm 25 \mathrm{BP}$ ) and 1380-1285 cal BC (POZ 84545: 3055 35 BP), respectively. The wooden remains within another arrowhead are of a similar date, 1370-1270 cal BC (MAMS 29472: $3038 \pm 29 \mathrm{BP})$. These new AMS dates are in close agreement with earlier results, confirming a date for the battlefield and related activities $c$. 1300-1250 cal BC (Terberger \& Heinemeier 2014; Terberger et al. 2018).

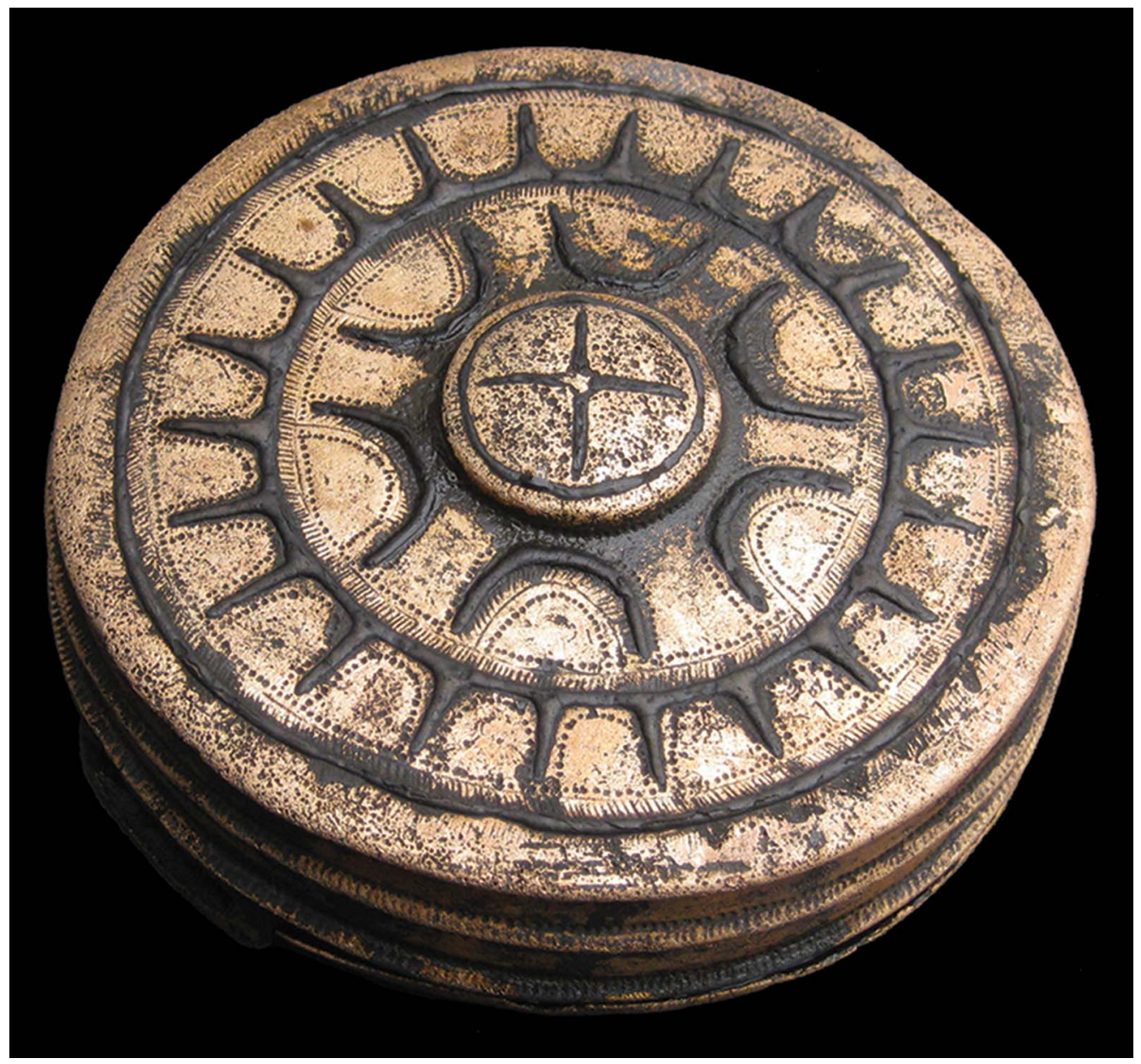

Figure 5. Star-ornamented belt box of type Dabel (diameter: $0.115 \mathrm{~m}$ ) found at Weltzin 28 (photograph by J. Krüger). (C) Antiquity Publications Ltd, 2019 


\section{Analysis of the deposit}

The 31 metal objects total $0.25 \mathrm{~kg}$ in weight and can be assigned to three broad categories (Figures 6-8 \& Table 1; Table S1 in the online supplementary materials (OSM)).

\section{Tools}

Three tools were identified: a knife, a chisel and an awl. The curved knife is of an unusual type (Figures 7.8); the upper side is reinforced with a $5 \mathrm{~mm}$-wide fin, which is more typically associated with sickles. The manufacture of knives from recycled sickles is known from other sites in northern and central Germany, as well as Bohemia (Prüssing 1982; Hohlbein 2016). A parallel for this knife comes from the Wodarg 31 site in the Tollense Valley (Dombrowsky 2014).

The chisel has a square cross section (Figures $7.9 \&$ Table 1 ) and shows clear use-marks on its top. A similar chisel, made of pure copper, was found in the Tollense River near Altentreptow (Kunkel 1940). A further parallel is a punch found in a hoard at Golchen, $6 \mathrm{~km}$ farther downstream, and dated to the transition from periods II-III (c. $1300 \mathrm{cal} \mathrm{BC)}$ (Schmidt 2014). Simple bronze chisels of this type are rare in the older Nordic Bronze Age (2000-1200 cal BC) (Schubart 1972; Willroth 1985) and more common in Central Europe. A few examples are known from large scrap metal hoards of the Middle Bronze Age (c. 16001300 cal BC) in Bohemia (Kibbert 1984; Ríhovský 1992; Kytlicová 2007). The same applies to three tools made from bronze bars (length: $33 \mathrm{~mm}, 60 \mathrm{~mm}$ and $64 \mathrm{~mm}$ ), cut from strands of thick bronze wire (Figure 7.1-2 \& 7.4), also commonly associated with scrap metal hoards.

The awl, with a birch wood handle (Figure 7.7), is a typical item of personal equipment of the Bronze Age. Examples with a similar handle are known from oak-coffin burials of both sexes in Southern Scandinavia (Ille 1991; Willroth 1998). The decoration with rows of suspended triangles and ladder motifs is common for bronze objects of period III (Schubart 1972; Schmidt \& Jantzen 1999). The typological dating of the decoration is confirmed by the AMS date on the handle (see above).

\section{Various fragments}

In addition to complete objects, the deposit contained a number of smaller and mostly fragmented items. A small broken segment of twisted bronze wire that ends in a hook (Figure 7.3) might have belonged to a body ornament; twisted needles or brackets are typical of several types of fibulae (Kersten 1936). A fragment of a socketed lance head and part of an intentionally broken blade are also present (Figures $7.6 \& 8.4$ ). Two bladed objects, with air pockets indicating that they are failed casts, were probably broken up for recycling or exchange (Figure $8.11 \& 8.14$ ). Two further bronze fragments represent waste from casting channels (Figure 8.6-8.7).

Two small, flat fragments and a third loaf-shaped fragment are made of pure copper (>98 per cent) and are probably parts of ingots (Figure 8.1-8.3). Loaf-shaped bronze ingots are known from Urnfield Culture graves (Jockenhövel 1973, 1982); they came into use during the Middle Bronze Age and might have served as pre-monetary currency (Modl 2010). The two flat fragments display rough fracture planes and resemble the 


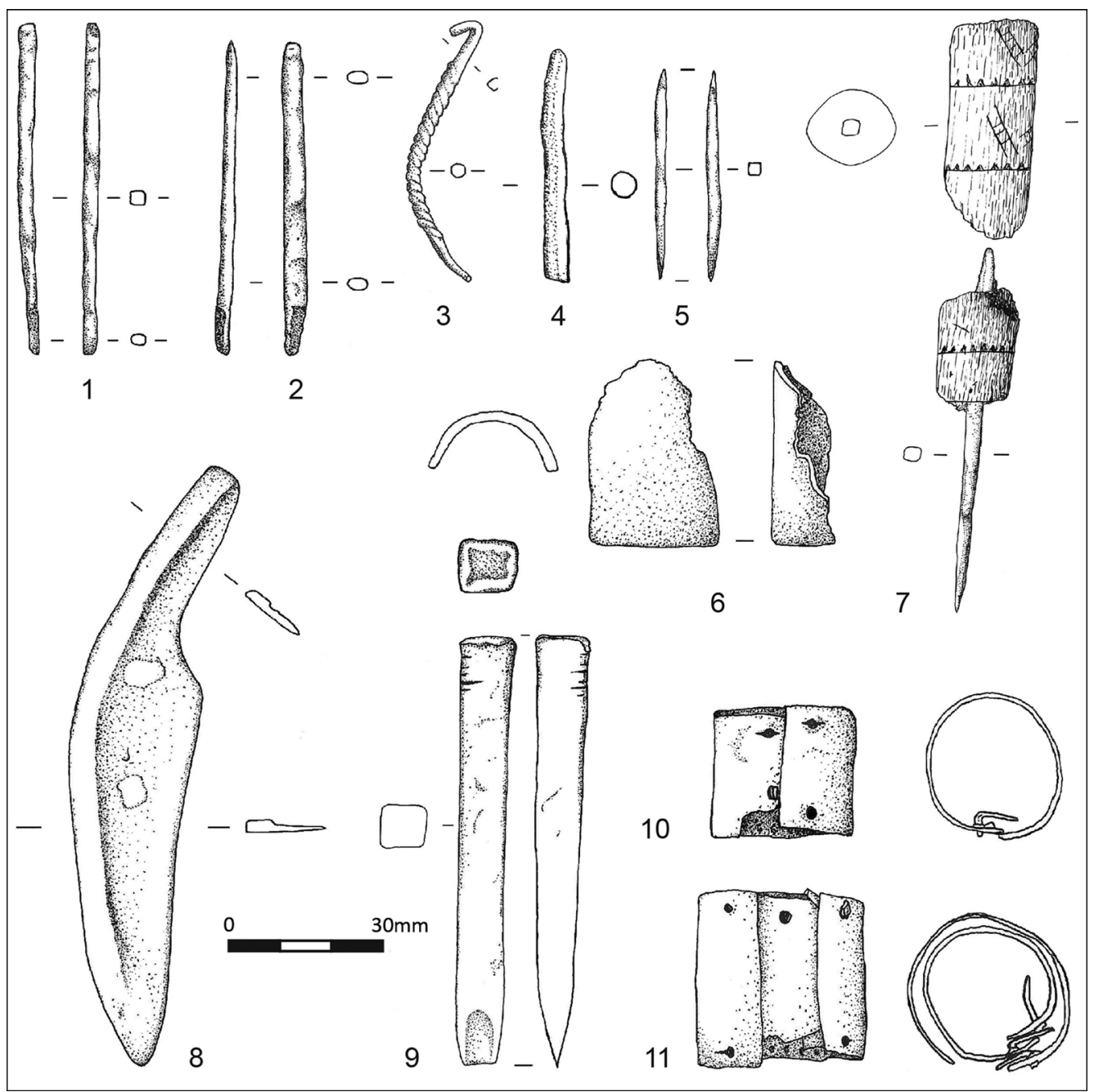

Figure 7. 1-2) Small chisels; 3) fibula fragment; 4) punch; 5) ingot or awl; 6) fragmented lance head socket; 7) awl with decorated wooden handle; 8) sickle knife; 9) chisel; 10-11) bronze sheet cylinders. Material of objects: 1-6 \& 8-11) bronze; 7) bronze and wood (drawing by T. Uhlig).

remains of bronze casting cakes. A short bronze rod (Figure 7.5) may also have been an ingot. Further fragments of blades or knifes were probably scrap ready for recycling or exchange (Figure 8.8-8.10).

\section{Sheet metal and cylindrical objects}

Twelve objects in the assemblage are made of hammered sheet bronze (Figure 7.10-11; Figure 8.9-10, 8.12-13 \& 8.15-19). Most of the pieces are folded or deformed; in two cases, signs of heat alteration may be visible. A group of three thin bronze sheet metal cylinders (approximately $1 \mathrm{~mm}$ thick and $240-290 \mathrm{~mm}$ in diameter) deserves special attention

(C) Antiquity Publications Ltd, 2019 


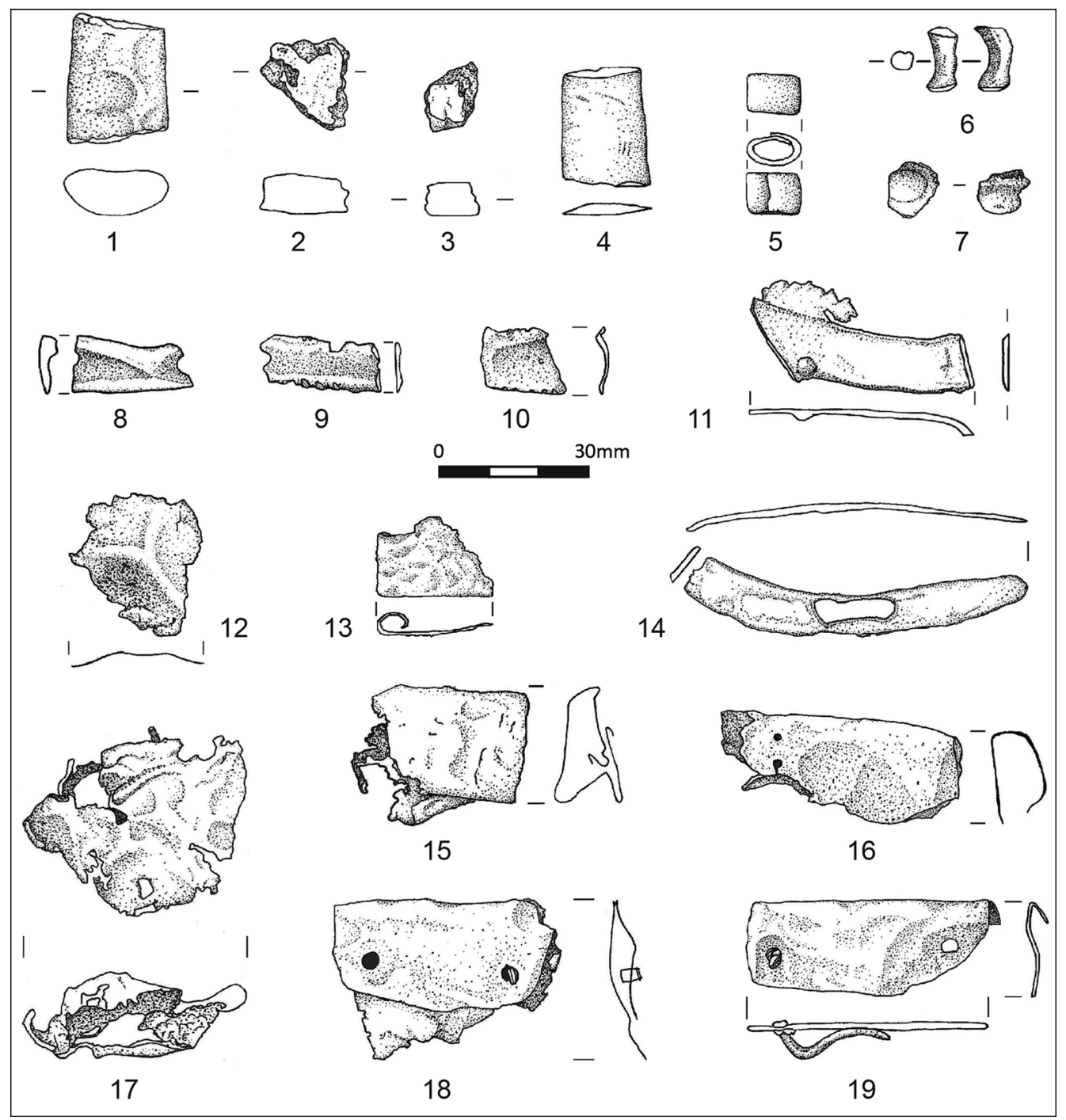

Figure 8. 1) Fragment of loaf-shaped ingot; 2-3) fragments of casting cakes; 4) blade fragment); 5) small ring; 6-11 హ。 14) casting waste; $13,16,18 \& 19)$ hammered sheet metal with nails; 15 \& 17) sheet metal damaged by heat. Material of objects: 1-3) copper; 4-19) bronze (drawing by T. Uhlig).

(Figure 7.10-7.11). These cylinders are made of rolled bronze sheets, and bear two perforations at each end with bronze nails still attached (Figure 9.3); the perforations were made by hammering the nails directly into the sheet. The sides of the cylinders are decorated with lines of punch marks. One of the folded pieces shows similar punch marks, but is completely deformed (Figure 8.18). The preservation of the cylindrical shape of these fragile sheet metal objects and the presence of the nails suggest that these were metal fittings for an object of organic material that perished following deposition. Groups of three to five cylindrical objects (without perforations) are also found in Bronze Age D

(C) Antiquity Publications Ltd, 2019 
Table 1. Summary of the 31 bronze finds from site Weltzin 28 (see Table S1 in the OSM for the full table).

\begin{tabular}{|c|c|c|c|c|c|c|c|}
\hline No & Inventory number & Object & Weight & Length & Width & Thickness & Figure \\
\hline \multicolumn{8}{|c|}{ Tools } \\
\hline 1 & $2016 / 1476.19$ & Knife/sickle & $25.68 \mathrm{~g}$ & $117 \mathrm{~mm}$ & $25 \mathrm{~mm}$ & $2 \mathrm{~mm}$ & 7.8 \\
\hline 2 & $2016 / 1476.20$ & Chisel & $49.48 \mathrm{~g}$ & $83 \mathrm{~mm}$ & $11 \mathrm{~mm}$ & $11 \mathrm{~mm}$ & 7.9 \\
\hline 3 & $2016 / 1476.21$ & Awl with wooden handle & $5.52 \mathrm{~g}$ & $100 \mathrm{~mm}$ & $4 \mathrm{~mm}$; handle $11 \mathrm{~mm}$ & Awl: $4 \mathrm{~mm}$; handle: $11 \mathrm{~mm}$ & 7.3 \\
\hline \multicolumn{8}{|c|}{ Ornaments } \\
\hline 4 & $2016 / 1476.22$ & Twisted bronze wire & $2.95 \mathrm{~g}$ & $50 \mathrm{~mm}$ & & $3 \mathrm{~mm}$ & 7.7 \\
\hline \multicolumn{8}{|c|}{ Bronze sheet metal objects } \\
\hline 5 & 2016/1476.23 & Bronze cylinder & $9.42 \mathrm{~g}$ & & $25 \mathrm{~mm}$ & $2 \mathrm{~mm}$ & 7.1 \\
\hline 6 & $2016 / 1476.24 a$ & Bronze cylinder & $24.12 \mathrm{~g}$ & & $32 \mathrm{~mm}$ & $2 \mathrm{~mm}$ & 7.11 \\
\hline 7 & $2016 / 1476.24 b$ & Bronze cylinder & $24.12 \mathrm{~g}$ & & $32 \mathrm{~mm}$ & $2 \mathrm{~mm}$ & 7.11 \\
\hline 8 & $2016 / 1476.35$ & Bronze sheet fragment & $6.23 \mathrm{~g}$ & $50 \mathrm{~mm}$ & $19 \mathrm{~mm}$ & $2 \mathrm{~mm}$ & 8.16 \\
\hline 9 & $2016 / 1476.36$ & Bronze sheet fragment & $0.81 \mathrm{~g}$ & $23 \mathrm{~mm}$ & $17.5 \mathrm{~mm}$ & $2 \mathrm{~mm}$ & 8.13 \\
\hline 10 & $2016 / 1476.40$ & Bronze sheet fragment & $0.58 \mathrm{~g}$ & $16 \mathrm{~mm}$ & $13 \mathrm{~mm}$ & $2 \mathrm{~mm}$ & 8.1 \\
\hline 11 & $2016 / 1476.41$ & Bronze sheet fragment & $2.03 \mathrm{~g}$ & $31 \mathrm{~mm}$ & $27 \mathrm{~mm}$ & $2 \mathrm{~mm}$ & 8.12 \\
\hline 12 & $2016 / 1476.44$ & Irregular bronze sheet fragment & $11.33 \mathrm{~g}$ & $35 \mathrm{~mm}$ & $46 \mathrm{~mm}$ & $2 \mathrm{~mm}$ & 8.17 \\
\hline 13 & $2016 / 1476.45$ & Bronze sheet fragment & $4.54 \mathrm{~g}$ & $47 \mathrm{~mm}$ & $20 \mathrm{~mm}$ & $2 \mathrm{~mm}$ & 8.16 \\
\hline 14 & $2016 / 1476.46$ & Bronze sheet fragment & $7.35 \mathrm{~g}$ & $46 \mathrm{~mm}$ & $31 \mathrm{~mm}$ & $2 \mathrm{~mm}$ & 8.18 \\
\hline 15 & $2016 / 1476.47$ & Bronze sheet fragment & $7.40 \mathrm{~g}$ & $36 \mathrm{~mm}$ & $27 \mathrm{~mm}$ & $2 \mathrm{~mm}$ & 8.15 \\
\hline 16 & $2016 / 1476.48$ & Bronze ring & $1.83 \mathrm{~g}$ & $11 \mathrm{~mm}$ & $8 \mathrm{~mm}$ & $7 \mathrm{~mm}$ & 8.5 \\
\hline \multicolumn{8}{|c|}{ Ingots } \\
\hline 17 & $2016 / 1476.29$ & Copper ingot & $23.03 \mathrm{~g}$ & $26 \mathrm{~mm}$ & $21 \mathrm{~mm}$ & $9 \mathrm{~mm}$ & 8.1 \\
\hline 18 & $2016 / 1476.30$ & Fragment of copper ingot & $4.35 \mathrm{~g}$ & $12 \mathrm{~mm}$ & $10 \mathrm{~mm}$ & $7.5 \mathrm{~mm}$ & 8.2 \\
\hline 19 & $2016 / 1476.31$ & Fragment of copper ingot & $10.31 \mathrm{~g}$ & $22 \mathrm{~mm}$ & $15 \mathrm{~mm}$ & $8 \mathrm{~mm}$ & 8.3 \\
\hline 20 & $2016 / 1476.26$ & Ingot (or chisel) & $4.00 \mathrm{~g}$ & $64.5 \mathrm{~mm}$ & $3 \mathrm{~mm}$ & $3 \mathrm{~mm}$ & 7.1 \\
\hline 21 & $2016 / 1476.25$ & Ingot (or chisel) & $1.02 \mathrm{~g}$ & $40 \mathrm{~mm}$ & $2 \mathrm{~mm}$ & $2 \mathrm{~mm}$ & 7.5 \\
\hline 22 & $2016 / 1476.28$ & Ingot (or chisel) & $4.59 \mathrm{~g}$ & $60 \mathrm{~mm}$ & $4 \mathrm{~mm}$ & $3 \mathrm{~mm}$ & $\begin{array}{c}7.2 \\
\text { atinued) }\end{array}$ \\
\hline
\end{tabular}

\section{Research}


Table 1. (Continued)

Summary of the 31 bronze finds from site Weltzin 28 (see Table $S 1$ in the OSM for the full table).

\begin{tabular}{|c|c|c|c|c|c|c|c|}
\hline No & Inventory number & Object & Weight & Length & Width & Thickness & Figure \\
\hline \multicolumn{8}{|c|}{ Weaponry } \\
\hline 23 & $2016 / 1476.33$ & Fragmented socket & $12.20 \mathrm{~g}$ & $38 \mathrm{~mm}$ & $24 \mathrm{~mm}$ & $2 \mathrm{~mm}$ & 7.6 \\
\hline 24 & $2016 / 1476.37$ & Blade fragment & $5.33 \mathrm{~g}$ & $24 \mathrm{~mm}$ & $18 \mathrm{~mm}$ & $3 \mathrm{~mm}$ & 8.4 \\
\hline \multicolumn{8}{|c|}{ Casting waste } \\
\hline 25 & $2016 / 1476.27$ & Small punch & $1.85 \mathrm{~g}$ & $33 \mathrm{~mm}$ & $3 \mathrm{~mm}$ & $3 \mathrm{~mm}$ & 7.4 \\
\hline 26 & $2016 / 1476.32$ & Casting waste & $2.75 \mathrm{~g}$ & & & & 8.7 \\
\hline 27 & 2016/1476.34, & Casting waste & $1.60 \mathrm{~g}$ & $12 \mathrm{~mm}$ & $7 \mathrm{~mm}$ & $4 \mathrm{~mm}$ & 8.6 \\
\hline 28 & $2016 / 1476.38$ & Bronze fragment & $3.79 \mathrm{~g}$ & $24 \mathrm{~mm}$ & $12 \mathrm{~mm}$ & $2 \mathrm{~mm}$ & 8.8 \\
\hline 29 & 2016/1476.39 & Casting waste? & $1.73 \mathrm{~g}$ & $23 \mathrm{~mm}$ & $10 \mathrm{~mm}$ & $2 \mathrm{~mm}$ & 8.9 \\
\hline 30 & $2016 / 1476.42$ & Casting waste & $4.57 \mathrm{~g}$ & $48 \mathrm{~mm}$ & $19 \mathrm{~mm}$ & $3 \mathrm{~mm}$ & 8.11 \\
\hline 31 & $2016 / 1476.43$ & Casting waste & $4.71 \mathrm{~g}$ & $69 \mathrm{~mm}$ & $10 \mathrm{~mm}$ & $2-3 \mathrm{~mm}$ & 8.14 \\
\hline
\end{tabular}




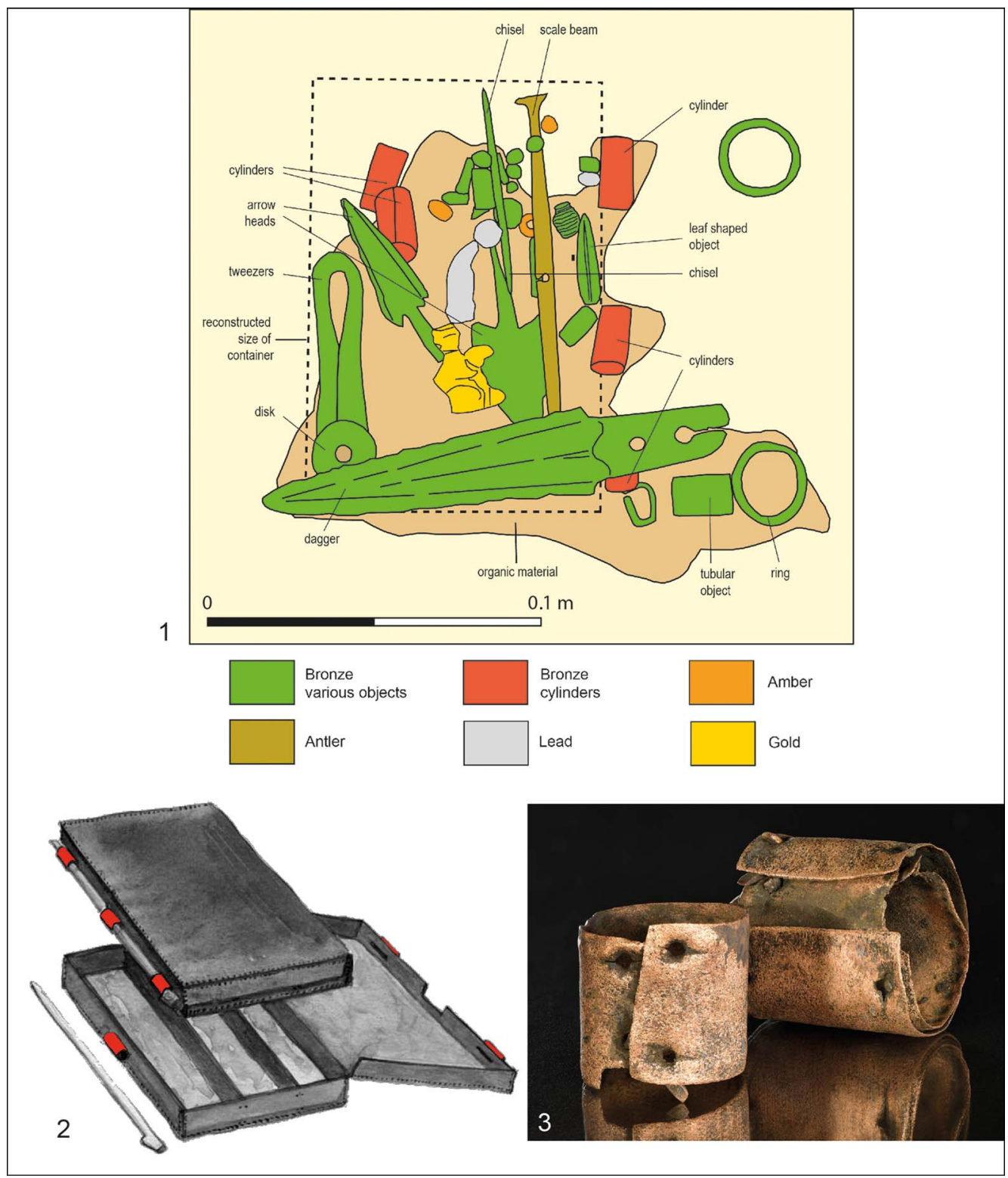

Figure 9. 1) Grave 298 from Migennes in eastern France (Bronze Age D, thirteenth century cal BC); drawing of set one from Migennes (probably a wooden box) containing personal equipment and cylindrical fittings; 2) the reconstruction of a wooden box including bronze fittings (marked in red) from Migennes, grave 298; 3) Weltzin 28, cylinders with nails (drawings 1-2: after Roscio et al. 2011; 3: photograph by V. Minkus).

(thirteenth century cal BC) burials in southern Germany and eastern France (Figures 9.1 $\& 10$ ). Where similar cylinders are preserved in situ, they have been interpreted as fittings for wooden boxes or organic bags that contained personal equipment, such as tools, scrap metal and balance weights (Pare 1999; Knöpke 2009; Roscio et al. 2011). The three

(C) Antiquity Publications Ltd, 2019 
cylinders from Weltzin 28 would have allowed the bag or box to be closed with a small wooden stick (Figure 9.2).

\section{Discussion}

The arrowheads and the human remains from Weltzin 28 are typical of the Tollense battlefield finds layer. The dress pins and the belt box, although not common for other parts of the excavated finds layer, have parallels in finds previously recovered from the valley (Jantzen $e$ t al. 2011; Dombrowsky 2014). The typology of these objects dates them firmly to period III, and it is possible that they are the personal equipment of combat victims. Dress pins, for example, were the most common ornament in graves at the all-male burial site of Neckarsulm, southern Germany (Knöpke 2009: 84). Deliberate deposition, however, might also explain these finds. The key question, therefore, is: are we dealing with an intentionally deposited hoard, or with the lost personal equipment of a warrior, perhaps represented by the human remains found nearby?

There is a long-standing debate on prehistoric metal depositions; the rigid distinction of early models between profane and sacred depositions was clearly too simplistic (e.g. Bradley 2013; Hansen 2013; Dietrich 2014; Hansen et al. 2016). Scrap metal hoards and other types of depositions in Bohemia and southern Germany from the Bronze Age B (c.1600 cal BC) onwards formed part of a tradition shared with the Carpathian Basin (Kytlicová 2007; Dietrich 2014). Characteristic hoard compositions in these regions (fragmented bronze objects, casting waste, lumps of raw bronze) have led to their initial interpretation as recycling deposits of traders or craftsmen (e.g. Stein 1976; Levy 1982; Huth 1997). The fact that scrap metal hoards from Bohemia contain objects spanning over 200 years favours the idea that they could be offerings of larger social groups (Vachta 2016). The steady increase in the circulation of bronze fragments at the expense of finished objects, during the course of the second millennium BC, suggests that bronze was exchanged as a commodity (e.g. Hänsel 1997; Primas 1997; Earle et al. 2015).

If we compare our Tollense Valley assemblage with contemporaneous and earlier scrap hoards from southern Central Europe, such as Bühl $(6.5 \mathrm{~kg})$ or Lažany $2(42 \mathrm{~kg})$, it becomes clear that the find from Weltzin 28 is much smaller. Pure scrap metal hoards are not known from the early Nordic Bronze Age. Scrap metal is sometimes found in later hoards, combined with tools and casting moulds (so-called 'founders' hoards'; Hundt 1997; Willroth 1998). The tools and scrap metal in the Weltzin 28 assemblage reflect those of the founder hoards of the Nordic Bronze Age, although no moulds are present. In conclusion, the scrap finds from Weltzin 28 clearly differ from the pattern of contemporaneous scrap hoards from both northern Central Europe and Southern Scandinavia.

Further finds connected to metalworking, including scrap metal, have been discovered in the Tollense Valley. At Golchen 18, approximately $6 \mathrm{~km}$ to the north, a scatter of bronze finds was recovered from dredged sediments on the riverbank. The assemblage contains an unfinished short-bladed sword, a socketed hammer, a small bronze anvil and a punch, as well as broken tools identified as scrap for recycling. The finds, typologically dated to the early period III, have been interpreted as belonging to a bronze metallurgist (Schmidt 2014). A similar assemblage, also containing a socketed object, perhaps a hammer, as well as scrap metal and (C) Antiquity Publications Ltd, 2019 
bracelet fragments, comes from a disturbed context close to the causeway (Kessin 12/Weltzin 13, Figure 1; Jantzen et al. 2017). Both assemblages reflect known hoard composition patterns and contain tools used for metalworking. In these cases, the interpretation as intentional depositions seems reasonable.

The situation around the few scrap metal finds at Weltzin 12 and the small metal objects at Weltzin 32 is different (Figure 1). At Weltzin 32, two tin rings and four small bronze spiral rolls were found in direct association with human bone. It is very probable that they were the personal belongings of a participant in the battle (Krüger et al. 2012). We suggest the same interpretation for the scrap metal finds from Weltzin 12. We also suggest that the finds from Weltzin 28 are the remains of an organic bag or box containing the personal equipment of a warrior, which he lost during the battle or which was deposited during post-battle activities (e.g. Vandkilde 2013).

As previously mentioned, the remains of organic containers in graves of the Bronze Age D in southern Central Europe provide a parallel for the cylindrical bronze fittings and other elements of the Weltzin 28 assemblage (Figures $9.1 \& 10$ ). These boxes are well known for containing personal equipment such as weights and balances, often displaying a combination of chisel and/or blade and awl (Pare 1999; Roscio et al. 2011). All known boxes appear to be associated with the graves of males and are often combined with swords. One container with cylindrical fittings is known from the all-male cemetery of Neckarsulm, a site interpreted as the burial ground of a warrior group (Knöpke 2009).

The fact that the best comparisons for the Weltzin 28 assemblage are found in the male (warrior) burials of southern Central Europe may indicate the possible origin of at least some of the warriors involved in the Tollense Valley battle. Typological similarities indicate connections to this region, including the socketed bronze arrowheads that are similar to those from sites in south-eastern Germany and Bohemia (Dombrowsky 2017). Different types of dress pins, a palstave of Bohemian type and a sword of Riegsee type are also typical objects from these southern regions (Figure 10; Dombrowsky 2014; Jantzen \& Terberger 2018). Some of the dress pins (types Mostkovice, Platĕnice, Pleszów; cf. Essen 1985: 58) found in the Tollense Valley are outliers of their main distributions, which makes trade a less probable explanation for their presence. Strontium isotope studies also support a non-local origin of some of the Tollense individuals (Price et al. 2017). In summary, it seems very possible that at least some of the combatants originated from southern Germany or Bohemia.

How can we conclusively interpret the composition of the Weltzin 28 assemblage? As described above, the unusual context of the find does not allow the precise reconstruction of the container. There are objects, such as the awl and chisel, which are probably utilitarian tools; some of the metal objects show evidence of intentional breaking, and the chisel was probably used for cutting bronze fragments. It has been proposed that the value of bronze was increasingly important during the Middle Bronze Age (e.g. Pare 2013). The association of boxes from Bronze Age $\mathrm{D}$ graves, exclusively male, with scale beams and weighting set, metalworking tools and metal fragments (Figure 9.1; Roscio et al. 2011; Ialongo 2019), suggests that they may have belonged to individuals dealing in the trade of metals, possibly as a form of currency (Pare 1999). The Weltzin 28 box may therefore represent the first discovery of evidence of this practice found in a non-funerary context.

(C) Antiquity Publications Ltd, 2019 


\section{Conclusion}

The archaeological record of the European Bronze Age is dominated by settlement finds, hoards and funerary evidence. The battlefield site at the Tollense River is very different: no formal burials and no traces of settlement are present in the valley. The many bronze finds suggest that offerings took place in the valley during period III, most probably connected to post-battle rituals. It is also probable, however, that some of the battle participants lost personal equipment in the river, saving it from the looting that inevitably followed the battle. We interpret the small bronze assemblage recovered from Weltzin 28 as a unique find of the typical personal belongings of a warrior who probably originated from southern Central Europe. In turn, this further supports the interpretation that the finds in the Tollense Valley testify to a large violent conflict of supra-regional scale. This conflict should be interpreted in the framework of the social and economic development that characterised Central Europe in the thirteenth century cal BC.

\section{Acknowledgements}

We thank Ronald Borgwardt as well as Frank and Sonja Nagel for their ongoing support of the project in the form of voluntary work in the valley. We also thank Manuela Schult for her identification of the wood species, and Knut Rassmann for his support in the use-wear analysis. Finally, we would like to thank the anonymous reviewers for their valuable comments. The project was financially supported by the German Science Foundation. N. Ialongo was supported by ERC-2014-CoG 'WEIGHTANDVALUE'.

\section{Supplementary material}

To view supplementary material for this article, please visit https://doi.org/10.15184/aqy. 2019.137

\section{References}

Bradley, R. 2013. Hoards and the deposition of metalwork, in H. Fokkens \& A. Harding (ed.) The Oxford handbook of the European Bronze Age: 121-39. Oxford: Oxford University Press. https://doi.org/10.1093/oxfordhb/ 9780199572861.013.0007

Brinker, U., S. Flohr, J. Piek \& J. Orschiedt. 2014. Getötet am Fluss: die bronzezeitlichen Menschenreste aus dem Tollensetal, Mecklenburg-Vorpommern, in T. Link \& H. Peter-Röcher (ed.) Gewalt und Gesellschaft. Dimensionen der Gewalt in ur-und frühgeschichtlicher Zeit (Universitätsforschungen zur Prähistorischen Archäologie 259): 111-20. Bonn: Rudolf Habelt.

Dietrich, O. 2014. Learning from 'scrap' about Late Bronze Age hoarding practices: a biographical approach to individual acts of dedication in large metal hoards of the Carpathian Basin. European Journal of Archaeology 17: 468-86.
https://doi.org/10.1179/1461957114Y. 0000000061

Dombrowsky, A. 2014. Bronzezeitliche Metallfunde aus dem Gebiet der mittleren Tollense unter besonderer Berücksichtigung der Flussfunde, in D. Jantzen, J. Orschiedt, J. Piek \& T. Terberger (ed.) Tod im Tollensetal. Forschungen zu den Hinterlassenschaften eines bronzezeitlichen Gewaltkonfliktes in Mecklenburg-Vorpommern (Beiträge zur Ur- und Frühgeschichte Mecklenburg-Vorpommerns 50): 131-80.

Schwerin: Landesamt für Kultur und Denkmalpflege Mecklenburg-Vorpommern. - 2017. Der gefiederte Tod in Zeiten des Umbruchs

-Bronzene Waffenfunde von der Fundstelle im Tollensetal, Mecklenburg-Vorpommern, in D. Brandherm \& B. Nessel (ed.) Phasenübergänge und Umbrüche im bronzezeitlichen Europa (Universitätsforschungen zur Prähistorischen Archäologie 297): 143-157. Bonn: Rudolf Habelt.

Earle, T., J. Ling, C. Uhnèr, Z. Stos-Gale \& L. Melheim. 2015. The political economy and 
metal trade in Bronze Age Europe: understanding regional variability in terms of comparative advantages and articulations. European Journal of Archaeology 18: 633-57. https://doi.org/10.1179/1461957115Y. 0000000008

Essen, R. 1985. Die Nadeln in Polen II (mittlere Bronzezeit). Prähistorische Bronzefunde XIII 9. Stuttgart: Steiner.

HäNSEL, B. 1997. Gaben an die Götter-Schätze der Bronzezeit Europas-eine Einführung, in W. Menghin \& B. Hänsel (ed.) Gaben an die Götter. Schätze der Bronzezeit Europas: 11-22. Berlin: SMPK.

Hansen, S. 2013. Parallele Raumkonzepte: Bronzezeitliche Rituallandschaften, in S. Hansen \& M. Meyer (ed.) Parallele Raumkonzepte: 157-74. Berlin \& Boston: de Gruyter. https://doi.org/10.1515/9783110291216

Hansen, S., D. Neumann \& T. Vachta. 2016. Raum, Gabe und Erinnerung: Einführung in den Tagungsband, in S. Hansen, D. Neumann \& T. Vachta (ed.) Raum, Gabe und Erinnerung. Weihgaben und Heiligtümer in prähistorischen und antiken Gesellschaften: 7-15. Berlin: Excellenzcluster Topoi FU Berlin.

Hohlbein, M. 2016. Die Messer in Süd-und Westdeutschland (Prähistorische Bronzefunde VII 6). Stuttgart: Franz Steiner.

Hundt, H.-J. 1997. Versuch zur Deutung der Depotfunde der nordischen jüngeren Bronzezeit unter besonderer Berücksichtigung Mecklenburgs, in F. Lüth \& U. Schoknecht (ed.) Die jüngere Bronzezeit in Mecklenburg: 28-98. Lübstorf: Landesamt für Kultur und Denkmalpflege Mecklenburg-Vorpommern

Huth, C. 1997. Westeuropäische Horte der Spätbronzezeit. Fundbild und Funktion (Regensburger Beiträge zur Prähistorischen Archäologie 3). Regensburg: Universitätsverlag.

IALONGO, N. 2019. The earliest balance weights in the West: towards an independent metrology for Bronze Age Europe. Cambridge Archaeological Journal 29: 1-22.

https://doi.org/10.1017/S0959774318000392

ILLE, P. 1991. Totenbrauchtum in der älteren Bronzezeit auf den dänischen Inseln (Internationale Archäologie 2). Rahden: Marie Leidorf.

Jantzen, D. \& T. Terberger. 2018. Die Schlacht im Tollensetal und ihre Bedeutung für die Geschichte des Krieges, in M. Wemhoff \&
M. Rind (ed.) Bewegte Zeiten. Archäologie in Deutschland: 270-81. Petersberg: Michael Imhof.

JantZen, D., U. Brinker, J. Orschiedt, J. Heinemeier, J. Piek, J. Krüger, G. Lidke, H. Lübke, R. Lampe, S. Lorenz, M. Schult \& T. Terberger. 2011. A Bronze Age battlefield? Weapons and trauma in the Tollense Valley, north-eastern Germany. Antiquity 85: 417-433. https://doi.org/10.1017/S0003598X00067843

Jantzen, D., G. Lidke, J. Dräger, J. Krüger, K. Rassmann, S. Lorenz \& T. Terberger. 2017. An Early Bronze Age causeway in the Tollense Valley, Mecklenburg-Western Pomerania-the starting point of a violent conflict 3300 years ago? Berichte der Römisch-Germanischen Kommission 95: 13-49. https://doi.org/10.11588/berrgk.2017.0.44423

JoCKENHÖvel, A. 1973. Urnenfelderzeitliche Barren als Grabbeigaben. Archäologisches Korrespondenzblatt 3: 23-28.

- 1982. Zeugnisse der primären Metallurgie in Gräbern der Bronze und Alteisenzeit Mitteleuropas. Archeologia Polski 27: 293-301.

Kersten, K. 1936. Zur älteren nordischen Bronzezeit. Kiel: Wachholtz.

Kibbert, K. 1984. Die Äxte und Beile im mittleren Westdeutschland (Prähistorische Bronzefunde IX 10). München: C.H. Beck.

KNöPKE, S. 2009. Der urnenfelderzeitliche Männerfriedhof von Neckarsulm. Forschungen und Berichte zur Ur- und Frühgeschichte in Baden-Württemberg 116. Stuttgart: Theiss.

Krüger, J., F. Nagel, S. Nagel, D. Jantzen, R. Lampe, J. Dräger, G. Lidke, O. Mecking, T. Schüler \& T. Terberger. 2012. Bronze Age tin rings from the Tollense Valley in northeastern Germany. Prähistorische Zeitschrift 87: 29-43. https://doi.org/10.1515/pz-2012-0002

KunKel, O. 1940. Urgeschichtliche Volkskunde, Landesgeschichte und Stadtkultur, kirchliche Kunst. Baltische Studien Neue Folge 42: 274-342.

KytuicovÁ, O. 2007. Jungbronzezeitliche Hortfunde in Böhmen (Prähistorische Bronzefunde XX 12). Stuttgart: Franz Steiner.

LEVY, J.E. 1982. Social and religious organization in Bronze Age Denmark: an analysis of ritual hoard finds (British Archaeological Reports International series 124). Oxford: British Archaeological Reports. 
Lidke, G., T. Terberger \& D. Jantzen. 2015. Das bronzezeitliche Schlachtfeld im TollensetalFehde, Krieg oder Elitenkonflikt? in H. Meller \& M. Schefzik (ed.) Krieg — eine archäologische Spurensuche. Begleitband zur Sonderausstellung im Landesmuseum für Vorgeschichte Halle (Saale): 337-46. Halle/Saale: Theiss.

Lidke, G., D. JANTZen, S. Lorenz \&

T. Terberger. 2018. The Bronze Age battlefield in the Tollense Valley, Mecklenburg-Western Pomerania, north-east Germany-conflict scenario research, in M. Fernández-Götz \& N. Roymans (ed.) Conflict archaeology: materialities of collective violence in Late Prehistoric and Early Historic Europe (EAA Themes in Contemporary Archaeology 5): 61-68. Abingdon: Routledge. https://doi.org/10.4324/9781315144771-6

Mods, D. 2010. Zur Herstellung und

Zerkleinerung von plankonvexen Gusskuchen in der spätbronzezeitlichen Steiermark, Österreich. Experimentelle Archäologie in Europa 9: 127-51.

Pare, C. 1999. Weights and weighing in Bronze Age Europe, in Eliten der Bronzezeit. Ergebnisse zweier Kolloquien in Mainz und Athen

2. Monographien des Römisch-Germanisches Zentralmuseum Bonn 43: 421-514.

- 2013. Weighing, commodification and money, in H. Fokkens \& A. Harding (ed.) The Oxford handbook of the European Bronze Age: 508-27. Oxford: Oxford University Press.

Price, T.D., R. Frei, U. Brinker, G. Lidke, T. Terberger, K.M. Frei \& D. Jantzen. 2017. Multi-isotope proveniencing of human remains from a Bronze Age battlefield in the Tollense Valley in northeast Germany. Journal of Archaeological and Anthropological Science 11: 3349. http://doi.org/10.1007/s12520-017-0529-y

Primas, M. 1997. Bronze Age economy and ideology: Central Europe in focus. Journal of European Archaeology 5: 115-30. https://doi.org/10.1179/096576697800703593

PrüssInG, P. 1982. Die Messer im nördlichen Westdeutschland Schleswig-Holstein, Hamburg und Niedersacbsen (Prähistorische Bronzefunde VII 3). München: C.H. Beck.

Ř́ínovsкx́, J. 1992. Die Äxte, Beile, Meißel und Hämmer in Mähren (Prähistorische Bronzefunde IX 17). Stuttgart: Franz Steiner.

Roscio, M., J.-P. Delor \& F. Muller. 2011. Late Bronze Age graves with weighing equipment from eastern France: the example of Migennes 'Le Petit Moulin' (dép. Yonne), burial no. 298.

Archäologisches Korrespondenzblatt 41: 173-87.

Sснміdт, J.-P. 2014. Der älterbronzezeitliche Werkzeughort von Golchen, Lkr. Mecklenburger Seenplatte, in D. Jantzen, J. Orschiedt, J. Piek \& T. Terberger (ed.) Tod im Tollensetal. Forschungen $z u$ den Hinterlassenschaften eines bronzezeitlichen Gewaltkonfliktes in Mecklenburg-Vorpommern (Beiträge zur Ur- und Frühgeschichte Mecklenburg-Vorpommerns 50): 181-90. Schwerin: Landesamt für Kultur und Denkmalpflege Mecklenburg-Vorpommern.

Schmidt, J.-P. \& D. Jantzen. 1999. Ein Hortfund der Periode III aus Neustrelitz, Lkr. Mecklenburg-Strelitz. Bodendenkmalpflege in Mecklenburg-Vorpommern Jahrbuch 47: 7-127.

Schubart, H. 1972. Die Funde der älteren Bronzezeit in Mecklenburg (Offa Bücher 26). Neumünster: Wachholtz.

STEIN, E. 1976. Bronzezeitliche Hortfunde in Süddeutschland: Beiträge zur Interpretation einer Quellengattung (Saarbrücker Beiträge zur Altertumskunde 23). Bonn: Habelt.

Terberger, T. \& J. Heinemeier. 2014. Die Fundstellen im Tollensetal und ihre absolute Datierung, in D. Jantzen, J. Orschiedt, J. Piek \& T. Terberger (ed.) Tod im Tollensetal. Forschungen $z u$ den Hinterlassenschaften eines bronzezeitlichen Gewaltkonfliktes in Mecklenburg-Vorpommern (Beiträge zur Ur- und Frühgeschichte Mecklenburg-Vorpommerns 50): 101-16. Schwerin: Landesamt für Kultur und Denkmalpflege Mecklenburg-Vorpommern.

Terberger, T., A. Dombrowsky, J. Dräger, D. Jantzen, J. Krüger \& G. LidKe. 2014. Professionelle Krieger in der Bronzezeit vor 3300 Jahren? Zu den Überresten eines Gewaltkonfliktes im Tollensetal, Mecklenburg-Vorpommern, in T. Link \& H. Peter-Röcher (ed.) Gewalt und Gesellschaft. Dimensionen der Gewalt in ur- und frühgeschichtlicher Zeit (Universitätsforschungen zur prähistorischen Archäologie 259): 93-110. Bonn: Habelt.

Terberger, T., D. Jantzen, J. Krüger \& G. Lidke. 2018. Das bronzezeitliche Kampfgeschehen im Tollensetal—ein Großereignis oder wiederholte Konflikte? in S. Hansen \& R. Krause (ed.) Bronzezeitliche Burgen zwischen Taunus und Karpaten Universitätsforschungen zur 
prähistorischen Archäologie 319 (Prähistorische Konfliktforschung 2): 103-24. Bonn: Habelt.

Ulrich, J. 2008. Neue Baggerfunde aus der Tollense im Raum Kessin-Weltzin, Landkreis Demmin. Archäologische Berichte aus Mecklenburg-Vorpommern 15: 22-35.

VACHTA, T. 2016, Thesaurierungsprozesse bronzezeitlicher Hortfunde anhand ihrer Kompositionselemente, in S. Hansen, D. Neumann \& T. Vachta (ed.) Raum, Gabe und Erinnerung. Weihgaben und Heiligtümer in prähistorischen und antiken Gesellschaften: 93-118. Berlin: Excellenzcluster Topoi FU Berlin.

VANDKILDE, H. 2013. Warfare in Northern

European Bronze Age societies: twentieth-century presentations and recent archaeological research inquiries, in S. Ralph (ed.)
The archaeology of violence: interdisciplinary approaches (IEMA Proceedings 2): 37-62. Buffalo: State University of New York Press. von Quillfeldt, I. 1995. Die Vollgriffschwerter in Süddeutschland (Prähistorische Bronzefunde IV 11). Stuttgart: Franz Steiner.

Willroth, K.-H. 1985. Zu den Meißeln der älteren nordischen Bronzezeit. Offa 42: 393-430.

- 1998. Prunkbeil oder Stoßwaffe, Pfriem oder Tätowierstift, Tüllengerät oder Treibstachel. Anmerkungen zu einigen Metallobjekten der älteren nordischen Bronzezeit, in C. Becker, M.-L. Dunkelmann, C. Metzner-Nebelsick, H. Peter-Röcher, M. Roder \& B. Terzan (ed.) Chronos. Beiträge zur prähistorischen Archäologie zwischen Nord- und Südosteuropa. Festschrift B. Hänsel: 469-96. Espelkamp: Marie Leidorf.

Received: 26 November 2018; Revised: 25 March 2019; Accepted: 12 April 2019

(C) Antiquity Publications Ltd, 2019 